\title{
Black blood TPM imaging at 3 T: comparison of two SAR reducing black blood methods
}

\author{
Anja Lutz ${ }^{* 1}$, Axel Bornstedt ${ }^{1}$, Peter Bernhardt ${ }^{1}$, Vinzenz Hombach ${ }^{1}$, \\ Nico Merkle1, Robert Manzke ${ }^{2}$ and Volker Rasche ${ }^{1}$
}

Address: ${ }^{1}$ University Hospital of Ulm, Ulm, Germany and ${ }^{2}$ Philips Research Europe, Hamburg, Germany

* Corresponding author

from 13th Annual SCMR Scientific Sessions

Phoenix, AZ, USA. 21-24 January 2010

Published: 21 January 2010

Journal of Cardiovascular Magnetic Resonance 20 I0, I2(SuppI I):P89 doi: 10.1 I86/I532-429X-I2-SI-P89

This abstract is available from: http://jcmr-online.com/content/I2/SI/P89

(c) 2010 Lutz et al; licensee BioMed Central Ltd.

\section{Introduction}

For tissue phase mapping (TPM) the suppression of the blood pool is necessary to reduce flow related artifacts. Black blood contrast in CINE imaging can be obtained using spatial presaturation. At high field MR systems, however, spatial presaturation considerably increases the specific absorption rate (SAR). Due to SAR limitations the number of measured heart phases is limited, since idle times have to be introduced into the sequence.

\section{Purpose}

The aim of this study is to evaluate two different approaches for SAR reduced black-blood CINE imaging.

\section{Methods}

13 volunteers were enrolled in this study. Image acquisition was performed on a $3 \mathrm{~T}$ whole body MR scanner with 32 element receive coil. One mid-slice short-axis view was acquired. For respiratory motion compensation navigator-gating was performed. Black blood imaging was performed using two saturation slabs adjacent to the imaged slice. Tissue phase mapped images were acquired using a segmented gradient-echo phase contrast sequence. The acquisition parameter were: $\mathrm{TE} / \mathrm{TR}=5 \mathrm{~ms} / 7 \mathrm{~ms}$, flip angle $=30^{\circ}, \mathrm{FOV}=340 \times 340 \mathrm{~mm}^{2}$, in-plane resolution: $2 \times 2$ $\mathrm{mm}^{2}$, slice thickness $=8 \mathrm{~mm}, \mathrm{VENC}=30 \mathrm{~cm} / \mathrm{s}, \mathrm{B} 1$-amplitude $=8 \mu \mathrm{T}$. One sequence without further $\mathrm{SAR}$ reduction, one sequence with SAR reduction by reducing the flipangle to $53^{\circ}$ and one sequence with alternating presaturation pulses was applied (Schema in Figure 1). The $53^{\circ}$ were chosen since this flip angle allows the same heartphase number as the alternated application of saturation pulses approach. For the reduced SAR sequences the number of maximum heart phases is 21 for $60 \mathrm{bpm}$ compared to $13 \mathrm{bpm}$ for the sequence without SAR reduction. For comparison of the methods, the blood-myocardial contrast and the correlation coefficient between the obtained radial velocity curves were calculated.

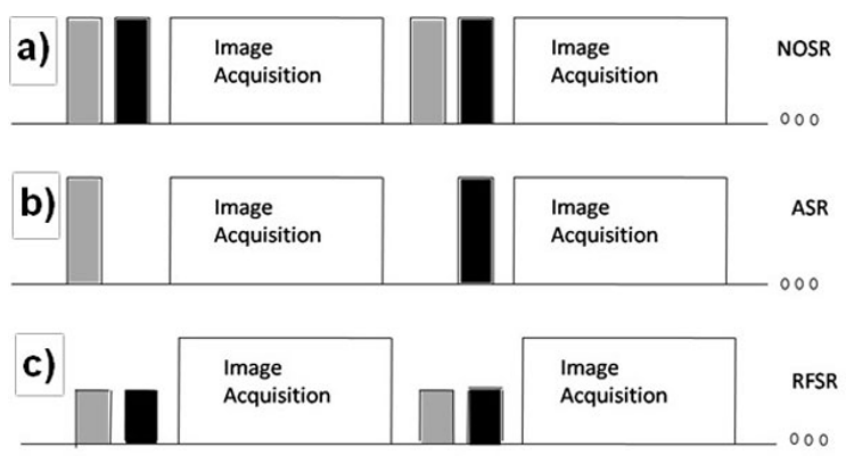

Figure I

Schema of different sequences. a) Both presaturation pulses were applied; b) presaturation pulses were applied in alternated fashion; c) presaturation pulse flip angle was reduced to $53^{\circ}$. 


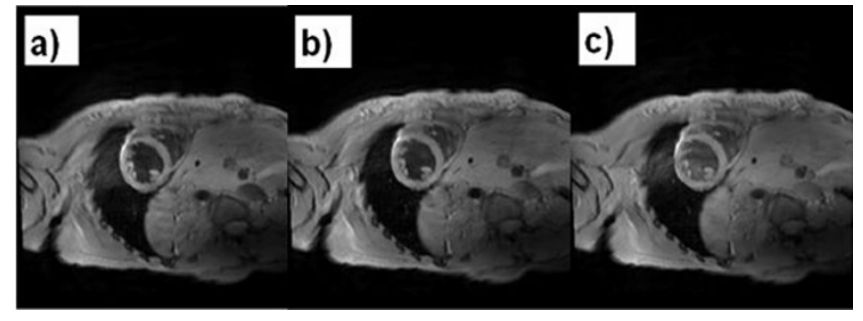

Figure 2

Black blood images acquired by a sequence with a) application of both presaturation pulses; b) application of alternating presaturation pulses; c) presaturation pulses with reduced flip angle.

\section{Results}

Figure 2 shows the black blood images obtained by the three different techniques. The contrast between myocardium and blood pool is $0.45 \pm 0.04$ for the sequence without SAR reduction, $0.42 \pm 0.04$ for the sequence with the alternating saturation pulses and $0.36 \pm 0.04$ for the sequence with reduced flip angle of presaturation pulses. The correlation coefficients between the sequence with alternating presaturation pulses or reduced presaturation flip angle and the sequence without SAR reduction was $0.96 \pm 0.03$ and $0.96 \pm 0.02$.

\section{Conclusion}

For black-blood suppression at high field strength combined with TPM the alternated application of presaturation pulses is preferred because a better contrast between myocardium and blood could be obtained. With both techniques a better temporal resolution could be obtained without motion information loss.
Publish with Bio Med Central and every scientist can read your work free of charge

"BioMed Central will be the most significant development for disseminating the results of biomedical research in our lifetime. "

Sir Paul Nurse, Cancer Research UK

Your research papers will be:

- available free of charge to the entire biomedical community

- peer reviewed and published immediately upon acceptance

- cited in PubMed and archived on PubMed Central

- yours - you keep the copyright

Submit your manuscript here:

http://www.biomedcentral.com/info/publishing_adv.asp
BioMedcentral 